\title{
New Record of Small White Water Lily
}

By E. Kuyt, Department of Natural Resources, Hudson Bay

This summer I found the Small White Water Lily, Nymphaea tetragona Georgi ssp. leibergii (Morong) Porsild, in Leaf Lake about 12 miles nontheast of Hudson Bay, Saskatchewan. Since A. J. Breitung's "Annotated Catalogue of the Vascular Flora of Saskatchewan" (The American Midland Naturalist, Vol. 58, pp. 1-72, 1957) lists this species only for the Saskatchewan River near Cumberland Lake this is a new locality record for the species. A pressed specimen has been sent to trie herbarium in Regina.

Since this species occurs in Asia and North Europe as well as eastern North America it is interesting to speculate about the absence of this plant in western North America. Has the species migrated across the Atlantic Ocean and is it still spreading westward? Was the species once circumpolar in its distribution until the last ice age pushed it out of northern North
America? In this case, too, it is probably now migrating westward.

The distribution of plants does change and it is interesting to consider the methods of dissemination of a water plant such as Nymphaea. No doubt the seeds of these plants are spread by water and once they become established in a river it will only be a matter of time before they are found at various spots downstream. But how do these plants "move" upstream or across divides? Leaf Lake and Cumberland Lake are on two different waterways and there are high hills between them. Since these lakes are on a north-south route much. frequented by waterfowl I can't help wondering if seeds could be carried by birds. Could seeds remain viable while passing through the digestive tract of birds or can the seeds be carried externally, stuck to the feathers or feet? I would like to know.

\section{A Second Can. Record of Oxytropis besseyi}

By G. F. Ledingham, Regina

On August 8, 1959, while the International Grassland Tour was in Swift Current I had, thanks to J. B. Campbell and Keith Best, a brief opportunity to look at the rerbarium of the Canada Department of Agriculture at the Experimental Farm. Among specimens of Astralagus missouriensis Nutt. I found one collection which did not fit. Superficially it looked like young specimens of Astralagus missouriensis for the leaves were silvery-canescent and the flowers were purple. Close examination showed that it was stemless, the type of pubescence was different and the keel was sharp pointed. This collection was actually Oxytropis besseyi (Rydb.) Blank.

In 1956 John $\mathrm{H}$. Hudson found Oxytropis besseyi on a high butte south of Canopus, Saskatchewan. Mr. Hudson had his specimen identified by R. C. Barneby and it was reported in the Blue Jay $(15: 74,1957)$ as the first record of this species for Canada. Mr. Hudson showed me the site at Canopus in 1957 and I have one plant growing in the garden at Regina College. It has tight clusters of beautiful reddish flowers which apparently turn purple when dried as a herbarium specimen.

Tr:e specimen in the herbarium at Swift Current (No. 526) was collected by J. Looman, on the slope of an eroded hill at Val Marie, June 16, 1955. This location must be about 68 miles west of the Canopus location.

Oxytropsis besseyi is a $2 \mathrm{n}=16$ species with relatives in Asia. It must, like man himself, have migrated into America through Alaska during some inter-glacial period and then spread southward. During one of the last ice ages it must have become extinct in Canada except possibly in the two locations reported here. It is interesting that this species has been unable to spread northward or has made but slow movement northward in the ten thousand years since the last glaciation. 